\title{
The Portrayal of the History of Angst in the Novels Jane Eyre and Wide Sargasso Sea by Charlotte Bronte and Jean Rhys
}

\begin{abstract}
Farhana Haque
PhD Research Fellow Academy of Brunei Studies University of Brunei Darussalam

Article History

Received: 06.10.2020

Accepted: 22.10 .2020

Published: 04.11.2020

Journal homepage:

https://www.easpublisher.com/easjhcs

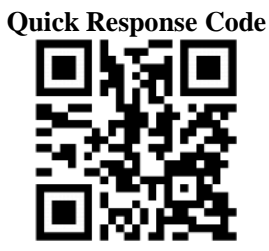

Abstract: This paper will map out the history of angst in the novel Jane Eyre and Wide Sargasso Sea by Charlotte Bronte and Jean Rhys. An important shift occurred during the late eighteenth century and early nineteenth century. In the social construct of the British identity this shift was ushered in with the loss of Britain's most important colonial acquisition which was America. The loss of American colonies in the late eighteenth century, disputed over identity and cultural hierarchy which were mainly domestic. However, with the loss of America and increasing angst as to Britain's imperial power within the European community, it became necessary for Britain to come together as a nationally and culturally homogenous metropolis in order to control its remaining colonies. Thus, as David Armitage points out the term "British" became colonized by the term "English", which came to stand for Great Britain (the mother country) and its inhabitants as a whole. In both of the novels Jane Eyre and Wide Sargasso Sea the loss of America and increasing angst as to Britain's imperial power within the imperial community were visible. And it effects both of the novels from the part of history.

Keywords: Jane Eyre, American colonies, Great Britain, European community, cultural hierarchy.
\end{abstract}

Copyright (C) 2020 The Author(s): This is an open-access article distributed under the terms of the Creative Commons Attribution 4.0 International License (CC BY-NC 4.0) which permits unrestricted use, distribution, and reproduction in any medium for non-commercial use provided the original author and source are credited.

\section{INTRODUCTION}

Englishness as a social construct then changed from something of domestic significance to something of imperial importance as it became a means of establishing and protecting the cultural borders of the metropolis against the inevitable and mutual process of cultural hybridization that occurred in the contact zones of empire. When the American colonies were firstly settled by the British in the seventeenth century they were viewed by Britons as economic satellites there for the purpose of generating wealth for the mother country[1]. Indeed, many government officials even viewed the settlers in the colonies as children, placed in their lands by a generous father, who had subsequently made every provision for their welfare. Its seems that, Britons just took the role of superiority over the American colonies and acted like their guardians. However, despite this sense of familial and cultural ties, Britons were very aware of the burgeoning gap between themselves and the Americans who were a mysterious and paradoxical people, physically distant but culturally close, engaging similar yet irritatingly different. In British newspapers we have seen the British might's depictions of the thirteen colonies through the image of native Americans, here actually lied the anxiety of British which has been manifested itself. Those cartoons in British newspapers were untouched and menacing. Linda Colley, a British historian suggested that, this depiction of the Americans indicated that the
British "were not unaware that imperial dominion might in the future shift from their own small island to the massive continent inhabited by their American colonists". These fears were not unfounded, as resistance to metropolitan authority increased when acted in parliament such as the stamp act of 1765 has passed without American representation. When the colonists started to openly rebel, Britain soon realized it had made a tactical error in its treatment of the colonies by not establishing royal authority as Spain had with its colonies. After such rebellion, like the Boston tea party of 1773, solidified many Britons believed that the Americans would never yield to the imperial authority of the crown and that war was necessary to enforce royal dominion. After the American declaration of independence in July 1776, Britons former views of the colonists as their English brethren has been shattered and the British began to perceive that their supposedly shared cultural identity and heritage with the American colonists were not shattered at all. The modified view of the colonists as a people separate from the British has strengthened by the colonists alliance with France, England's primary enemy, an alliance which the British took as a sigh that any affinity or connection between the colonists in America and the Englishmen in Britain have been severed. After observing the war of American colonies, the British started to feel that, they faced with the loss of their cultural and national identity. Believing in a shared Englishness and national 
loyalty which had provided them a false sense of security about their American colonies, therefore made Britain more susceptible to colonial revolt. In a narrower definition of Englishness, a shared sense of identity between domestic English subjects and British colonial subjects, which made Britain more diligent in its command and surveillance of its colonies. Linda Colley summarizes this shift in domestic cultural politics when she says: "In the half century after the American war, there would emerge in Great Britain a far more consciously and officially constructed patriotism which stressed attachment to the monarchy, the importance of empire the value of military and naval achievement, and the desirability of strong stable government by virtuous able and authentically British elite". Response to the American revolution which was particularly felt by English officials in the west Indies who denounced the action of the deluded North Americans, " saying that while rebellion could be tolerated, outright revolt could not. The creole colonizers vehement to revolution and dissension reflect a history of angst within the British Caribbean islands beginning in the 1730s with the Maroon rebellions in Jamaica. The population referred to as "Maroon" was composed primarily of runaway slaves and their descendants who engaged in guerrilla warfare with the white colonist and plantation owners in Jamaica. Eventually a treaty was happened between the Maroon leader and the government of Jamaica, exchanging loyalty to the crown for land. But such peace was temporary and evaporated with the dawning of the French revolution. These Maroon rebellions were soon followed by other rebellions such as slave revolts in Tobago between 1770 and 1776 and Tacky's rebellion in 1760 in Jamaica, which was happened for the Ashanti Negroes of the Akan linguistic group. Tacky's rebellion especially posed a threat to British control as it involved over a year because of slave's betrayal and resulted in the capture of several plantations and the slaying of white plantation owners. Such angst over rebellion was exacerbated by the success of the French and American revolutions during the late eighteen century. Slave rebellion continued with Fredon's rebellion in 1795, during which Grenada came temporarily entirely under the slaves control until British troops re-established order in July 1796. The British incline to maintain an cultural hierarchy in which the white English people have been universally understood to be privileged and superior while blacks and natives of the islands were always subservient and needing governance. Such hierarchy placed Britain in the difficult position of attempting to make its imperial subjects feel that they belonged within empire, therefore they have to have keep the sense of loyalty which will reinforcing the superiority of English people. Here it is certain that, the English people think, they have the superior crown which led them towards inherent right to rule their subordinate subjects. British anxiety over how to control their colonial populations. In December,
1791, Governor Mathews of Grenada informed the British government that most of the slaves did rebel in Saint Domingue and the initial report of rebellion marked the beginning of the Haitian revolution which lasted from 1799-1804, and a majority of the rebellious people had been imported from Africa. It was such a massive revolt in the Caribbean and the establishment of a sovereign black nation irrevocably changed the way Europe viewed the west Indian. Here its clear to make a note that, British people's smug about supremacy over Caribbean people have been demolished through that rebellious attack.

\section{Analysis of the Two Novels Jane Eyre and Wide Sargasso Sea from the Perspective of the Theme Called History of Angst}

The British wished to save their pride of supremacy and as a result the British saw Haiti as the ultimate affront to imperial order and control. As Silvio Torres-Saillant [3] pointed out in An intellectual History of the Caribbean, " To a large extent tenacious rise of a nation built by insurgent slaves contradicted and debunked the very logic upon which the international hegemony of the Christian west was predicted". Here lies the fear of British government, because they thought this symbol of black independence and self-governance would lead to revolution within their own colonies, especially those of Grenada and Jamaica. Because those countries showed the sign of rebellion in previous times. But as the English continued to settle in the colonies English cultural norms began to intrude in the west Indies. As a result the black slaves began to emulate the British norms which has been seen in Wide Sargasso Sea. Some of the characters in that novel continually attempt to act or be like the white people. Englishness became more important as a means of distinction between two groups that were becoming increasingly similar. Such similarity was dangerous. Englishness of the British people were able to widen the gap between the slaves and their owners. For example, Englishness was used to widen the gap between slave and master in the West Indies, Englishness was also used to widen the gap between white colonist and domestic Englishmen. Britain's success lies by their unique system of imperialism. And as their highest reward, they have achieved the geographic distance with the developed British ideology, well equipped military, political and economic methods in order to govern its satellites. Britain's supremacy also allowed to control the colonies through racial subjugation and disavow any knowledge or involvement. From this perspective two separate and distinct national histories arose in Britain. One is domestic history, and the other one is imperial history. Following this two practice here i can include David Armitage's theory: [1] “ British history is assumed to mean domestic history implies extraordinary history. The attributed character of the second empire as an empire built on military conquest, racial subjugation, economic exploitation and territorial expansion 
rendered its incompatible with the metropolitan norms of liberty, equality and the rule of law and demanded that the empire be exoticized and further differentiated from domestic history". Having these two divergent histories allowed Britain to simultaneously oppose slavery as morally depraved in Great Britain and yet practice slavery in its colonies to gain wealth. In Jane Eyre these two divergent histories can be appropriate for Mr Rochester and Jane Eyre's life histories. Because both of them received their fortunes through their affiliation with West Indies( Rochester's wife Bertha and Jane's uncle), yet the source of this West Indian wealth, namely the slave trade is never openly acknowledge. The result of this moral incongruence between Britons complicity with slavery and yet their absolution from it due to their supposed firm moral stance against it can be seen in Jean Rhys's Wide Sargasso Sea novel.

\section{CONCLUSION}

To sum up, we can say that the novel Jane Eyre was centred as unidentified male character whom the reader assumed to be $\mathrm{Mr}$ Rochester, continually noticed and inquired after evidence of slavery in Jamaica, yet never acknowledged any blame as an Englishman for what has done on there. He associated the names of past slave owners and places like massacre solely with the West Indies and its morally depraved inhabitants like Antoinette. While emancipation was declared in Britain in 1833 with the slavery abolition act, full emancipation did not take effect in the colonies until 1838. Many scholars believed that Jane Eyre has been written during the $1820 \mathrm{~s}$ or $1830 \mathrm{~s}$ in pre- emancipation England. Jane Eyre got examined through some contexts such as the economic struggle in Britain that was considered morally correct by the metropolis and the economically advantages for the empire. After examining scenes such as the one in which Bertha did set Thornfield on fire, some critics have begun to move toward a more political reading of the text and away from past feminist readings. To support this matter, Susan Meyer remarked that, instead of Bertha's rebellion at the end of the novel symbolizing women breaking free of gender oppression, "Bertha is meant to re-enact the slave rebellions in the Jamaican colonies during the late eighteen century. Such violence and aggression in Bertha places her firmly in the group of the inferior West Indian creole, and consequently elevates Jane to the role of the orderly English woman who mirrors Britain's sense of imperial control. Thus, from the history of rebellion and aggression perpetrated by the colonial subjects of the British empire to Britain's angst over outright revolution as seen in America and Haiti". Now a narrower definition of Englishness became essential to control satellite colonies from afar and to secure a permanent position of moral and cultural superiority for the British.

\section{REERENCE}

1. Armitage, D. (2000). The Ideological Origins of the British Empire. Cambridge: Cambridge university press.

2. Bronte, C. (1926). Jane Eyre. New York: the book league of America. P.

3. Torres, S. (2006). Silvio. Intellectual History of the Caribbean. New York: Palgrave Macmillan. 